\title{
Analisis Kualitas Jasa Pada Bisnis Perbankan Syariah Berdasarkan Adaptasi Model Carter
}

\author{
EFRITA SOVIYANTI \\ Fakultas Ekonomi Universitas Lancang Kuning Pekanbaru \\ Jalan Yos Sudarso KM 8 Rumbai \\ Telp (0761) 52581 email; efritasoviyantihrp@gmail.com
}

\begin{abstract}
This research aims knowing how big service quality factors from CARTER model influence customer satisfaction, knowing the rate of customer satisfaction of sharia bank that analyzed with CARTER model, and making improvement priority to enhance service quality for it. To fulfill the aims, it is used factor analysis and path analysis. The result of this research has got several conclusions( 1) Factor analysis showed that factogrouped to 8 factors. The eight factors is influencing customer satisfaction directly as big as $12,01 \%$ and indirectly as big as $36 \%$. (2)The rate of customer satisfaction of sharia banking that analyzed by CARTER model adaptation show that $56 \%$ respondents told satisfied over ally with sharia banking service in Pekanbaru. (3)Quality improvement can be done for reliability, competence, responsiveness, assurance, emphaty, tangible knowing the customer and compliance.
\end{abstract}

Keywords: Service quality, Customer satisfaction, SERVQUAL, CARTER Model.

Bank Syariah adalah bank umum yang melaksanakan kegiatan usaha berdasar prinsip syariah yang dalam kegiatannya memberikan jasa dalam lalu lintas pembayaran (UU no. 10 tahun 1998 tentang perubahan UU no. 7 tahun 1992 tentang perbankan). Bank dengan prinsip syariah yaitu bank yang mengikuti aturan perjanjian berdasarkan hukum islam antara bank dengan pihak lain untuk penyampaian dan atau pembiayaan kegiatan usaha, atau kegiatan lainnya yang sesuai dengan syariah (Bank Indonesia, 2000).

Sejalan dengan berkembangnya sistem perbankan nasional, perbankan syariah sebagai institusi yang menyediakan pelayanan jasa dibidang perbankan yang didasarkan pada prinsip syariah terus berkembang sejak diberlakukannya Undang-undang Nomor 7 Tahun 1992 dan Undang-undang Nomor 10 Tahun 1998.

Perbankan syariah dalam hal bidang penyedia jasa memiliki karakteristik yang mirip dengan perbankan konvensional. Perbedaan yang mendasar antara bank syariah dengan bank konvensional adalah terletak pada praktek menjalankan operasional bisnisnya, dimana operasionalnya berbasis prinsip syariah, dan prinsip inilah yang menjadi daya tarik yang tinggi bagi pelanggan untuk memanfaatkan jasa bank syariah. Menurut Karim (2005) ada beberapa tantangan yang dihadapi dunia perbankan kedepannya, diantaranya adalah kualitas layanan, aspek pengembangan produk, pengembangan SDM, pengembangan IT, dan aspek regulasi.

Kualitas layanan merupakan faktor kunci yang akan menjadi keunggulan daya saing bank syariah dibandingkan dengan pesaing bank syariah lainnya. Hal ini terjadi karena bank sebagai suatu perusahaan jasa, mempunyai ciri berupa mudah ditirunya suatu produk yang telah dipasarkan. Pada kondisi produk yang relatif beragam antar bank syariah, maka yang menjadi faktor penentu daya saing dari perbankan syariah adalah kualitas layanan yang diberikan oleh bank syariah kepada nasabahnya.

Menurut Russel (1996) kualitas memiliki beberapa peran penting bagi perusahaan dalam kontek persaingan, yaitu: 1) meningkatkan reputasi perusahaan, 2) menurunkan biaya, 3) meningkatkan pangsa pasar, 4) pertanggungjawaban produk, 5) memiliki dampak internasional, 6) penampilan produk atau layanan, 7) mewujudkan kualitas yang dinilai penting. Othman dan Lynn Owen dari University of 
Wales pada tahun 2001 mengembangkan model pengukuran kualitas jasa untuk mengukur kualitas jasa yang dijalankan dengan prinsip syariah, khususnya bisnis perbankan syariah. Model ini disebut sebagai Model CARTER.

Kota Pekanbaru saat ini menjadi daerah incaran baru industri perbankan syariah di Indonesia. Pertumbuhan kebun kelapa sawit sepuluh tahun terakhir juga membuka peluang pembiayaan syariah untuk pembangunan pabrik pengolahan kelapa sawit dengan kapasitas mini, pertumbuhan tersebut diiringi juga dengan marak nya bank-bank syariah membuka kantor cabang nya di Pekan baru. Jumlah penduduk yang sebagian besar menganut agama Islam juga menjadi pertimbangan bagi bank syariah untuk membuka cabang nya di Pekanbaru.

Berikut ini disajikan beberapa kajian pustaka yang mendukung permasalah dalam artikel ini sebagai berikut :Jasa merupakan komoditas tidak tahan lama dan tidak dapat disimpan. Namun menurut Stanton, Etzel, dan Walker (1991), ada pengecualian dalam karakteristik perisahbility dan penyimpanan jasa. Dalam kasus tertentu, jasa bisa disimpan, yaitu dalam bentuk pemesanan (misalnya reservasi tiket pesawat dan kamar hotel), peningkatan permintaan akan suatu jasa pada saat permintaan sepi (misalnya asuransi). Sebagai contoh, jasa asuransi dibeli oleh pelanggan, kemudian jasa tersebut ditahan oleh perusahaan asuransi sampai saat dibutuhkan oleh pemegang polis atau ahli waris yang bersangkutan. Dengan demikian, hal ini bisa dianggap sebagai suatu bentuk penyimpanan.

Dalam studi manajemen operasi, mutu atau kualitas ditekankan sebagai kemampuan kinerja operasi perusahaan yang paling dasar. Hal ini dikarenakan sangat sedikit konsumen akan mempertimbangkan untuk melaksanakan bisnis dengan sebuah perusahaan jika tingkat kualitas tidak cukup. Suatu perusahaan yang menekankan kualitas akan bekerja dengan konsisten untuk memberikan tingkat kualitas yang superior secara signifikan terhadap pesaingnya. Selanjutnya keuntungan yang sangat efektif melebihi pesaing mereka, dan mereka telah mencapai manfaat biaya dan profit yang signifikan dari strategi ini.

Selain itu juga Nasution (2004) menjelaskan ada beberapa definisi mutu atau kualitas yang dikemukakan oleh beberapa pakar, diantaranya adalah 1) Crosby (1979) menyatakan, bahwa kualitas adalah conformance to requirement, yaitu sesuai dengan yang disyaratkan atau distandarkan. Suatu produk memiliki kualitas apabila sesuai dengan standar kualitas yang telah ditentukan; 2) Deming (1982) menyatakan, bahwa kualitas adalah kesesuaian dengan kebutuhan pasar; 3) Feigenbaum (1986) menyatakan, bahwa kualitas adalah kepuasan pelanggan sepenuhnya (full customer satisfaction). Suatu produk berkualitas apabila dapat memberi kepuasan sepenuhnya kepada konsumen, yaitu sesuai dengan apa yang diharapkan konsumen atas suatu produk; 4) Garvin dan Davis (1994) menyatakan, bahwa kualitas adalah suatu kondisi dinamis yang berhubungan dengan produk, manusia/tenaga kerja, proses dan tugas, serta lingkungan yang memenuhi atau melebihi harapan pelanggan atau konsumen.

Sementara itu, Wyckof dalam Lovelock (1988) memberikan pengertian kualitas jasa sebagai tingkat kesempurnaan yang diharapkan dan pengendalian atas kesempurnaan tersebut untuk memenuhi keinginan konsumen, sedangkan menurut Parasuraman, et al (1988) kualitas jasa merupakan perbandingan antara layanan yang dirasakan (persepsi) konsumen dengan kualitas layanan yang diharapkan konsumen. Jika kualitas layanan yang dirasakan sama atau melebihi kualitas layanan yang diharapkan, maka layanan dikatakan berkualitas dan memuaskan.

Gronroos (1990) menyatakan bahwa kualitas layanan meliputi: 1) Kualitas fungsi, yang menekankan bagaimana layanan dilaksanakan, terdiri dari: dimensi kontak dengan konsumen, sikap dan perilaku, hubungan internal, penampilan, kemudahan akses, dan service mindedness; 2) Kualitas teknis dengan kualitas output yang dirasakan konsumen, meliputi harga, ketepatan waktu, kecepatan layanan, dan estetika output; 3) 
Reputasi perusahaan, yang dicerminkan oleh citra perusahaan dan reputasi di mata konsumen.

Menurut Zeithaml, Berry dan Parasuraman (1985) kualitas layanan dapat dilihat dari 10 dimensi yaitu: 1) Communication, penggunaan bahasa komunikasi yang bisa dipahami konsumen; 2) Credibility, kepercayaan konsumen terhadap penyedia layanan; 3) Security, keamanan konsumen, bebas resiko, bahaya, dan keraguraguan; 4) Knowing the customer, pemahaman penyedia layanan terhadap kebutuhan dan harapan konsumen; 4) Tangibles, dalam memberi layanan harus ada standar pengukurannya; 5) Reliability, konsistensi penyedia layanan dan kemampuan penyedia layanan dalam memenuhi janji; 6) Responsiveness, kemauan dan kesediaan penyedia layanan dalam memberi layanan; 7) Competence, kemampuan atau keahlian penyedia layanan dalam memberikan layanan; 8) Access, kemampuan pendekatan dan kemudahan penyedia layanan untuk bisa dihubungi oleh konsumen; dan 9) Courtesy, kesopanan, rasa hormat, perhatian dan keadilan penyedia layanan ketika berhubungan dengan konsumen.

Di antara sepuluh dimensi kualitas layanan diatas, menurut Parasuraman, et al. (1988) ada yang saling tumpang tindih, sehingga mereka menyodorkan lima dimensi kualitas layanan yang lebih sederhana, yaitu: 1) Tangibles (bukti fisik), yaitu bukti fisik dan menjadi bukti awal yang bisa ditunjukkan oleh organisasi penyedia layanan yang ditunjukkan oleh tampilan gedung, fasilitas fisik pendukung, perlengkapan, dan penampilan pekerja; 2) Reliability (keandalan), yaitu kemampuan penyedia layanan memberikan layanan yang dijanjikan dengan segera, akurat, dan memuaskan; 3) Responsiveness (daya tanggap), yaitu para pekerja memiliki kemauan dan bersedia membantu pelanggan dan memberi layanan dengan cepat dan tanggap; 4) Assurance (jaminan), yaitu pengetahuan dan kecakapan para pekerja yang memberikan jaminan bahwa mereka bisa memberikan layanan dengan baik; 5) Empathy (empati), yaitu para pekerja mampu menjalin komunikasi interpersonal dan memahami kebutuhan pelanggan.

Selama mengkonsumsi suatu produk, pelanggan akan memperoleh pengalaman mengenai kinerja suatu produk, dan ini akan menimbulkan perasaan puas atau tidak puas. Lele and Sheth (1991) seperti yang dikutip Purnama (2006) mendefinisikannya sebagai berikut: Customer Satisfaction is key to long term profitability and keeping the customer happy is everybody's business. Sedangkan Parasuraman, Zeithmal and Berry (1985) mendefinisikannya: Customer satifaction is customer perception of a single service experience.

Faktor-faktor yang membentuk perasaan puas atau tidak puas digambarkan dalam model kepuasan/ketidakpuasan seperti pada gambar 2.1. berikut ini.

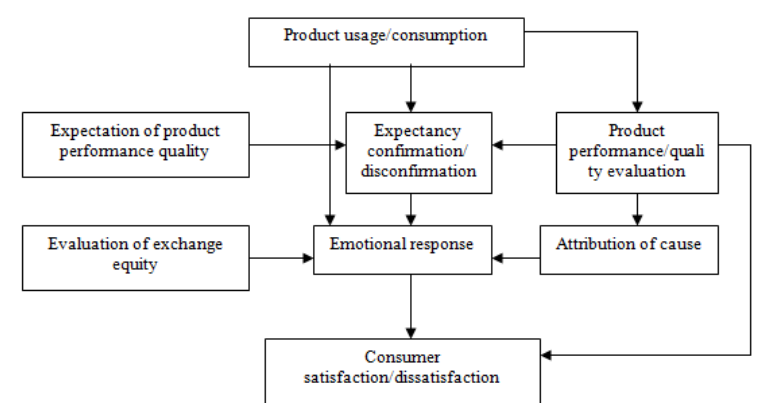

Gambar 1.

Model kepuasan/ketidakpuasan pelanggan (Assael, 1998)

Dalam model pada Gambar 2.1, pelanggan diasumsikan pertama kali mengkonsumsi produk tersebut. Berdasarkan pengalaman itu, pelanggan mengevaluasi kinerja produk secara keseluruhan. Penilaian kinerja suatu produk erat kaitannya dengan tingkat mutu dari produk tersebut. Persepsi mengenai mutu produk ini dibandingkan dengan harapan pelanggan terhadap kinerja produk itu. Proses evaluasi terjadi pada saat pelanggan membandingkan kinerja aktual dengan kinerja yang diharapkan. Berdasarkan hasil evaluasi ini, pelanggan akan memperoleh emosi yang dapat bersifat positif, negatif maupun netral tergantung apakah harapannya terkonfirmasi atau tidak. Respon emosional ini merupakan masukan 
dalam membentuk persepsi kepuasan atau ketidakpuasan secara keseluruhan. Sebagai tambahan, tingkat kepuasan atau ketidakpuasan juga dipengaruhi oleh hasil evaluasi terhadap nilai dari proses pertukaran. Dari atribut-atribut yang menghasilkan mutu atau kinerja dari suatu produk juga mempengaruhi sikap puas atau tidak puas.

\section{METODE}

Penelitian ini ditujukan kepada nasabah bank syariah yang ada di Pekanbaru, yang terdiri dari 5 bank syariah.Data primer diperoleh melalui penyebaran kuesioner terstruktur dimana responden mengisi sendiri kuesioner tersebut serta wawancara-wawancara terhadap para pegawai bank syariah untuk informasiinformasi lainnya.Kuesioner disebar di lima bank tersebut dengan masing-masing 35 responden sehingga total responden dalam penelitian ini adalah 175 responden.Metode sampling yang digunakan adalah metode purposive sampling dan convenience sampling.

Data yang telah dikumpulkan kemudian dianalisis dengan menggunakan statistik deskriptif. Dimensional faktor-faktor atau aitem-aitem CARTER diuji untuk meyakinkan bahwa dimensi faktor-faktor tersebut penting dan sesuai sebagai model.Setelah dilakukan analisis faktor dan diperoleh jumlah faktor yang terbentuk, selanjutnya dilakukan analisis jalur untuk mengetahui pengaruh langsung dan tidak langsung suatu faktor terhadap kualitas layanan di perbankan syariah. Tipe skala yang digunakan adalah Skala Likert antara 1 sampai dengan 5 .

\section{HASIL}

Kualitas jasa bank syariah di ukur dengan menggunakan kuesioner yang di adaptasi dari Model CARTER yang terdiri dari 3 aitem pertanyaan yang berisi tentang tingkat kepuasan nasabah bank syariah dalam melakukan transaksi dengan bank syariah. Berikut adalah tabel hasil dari kepuasan nasabah bank syariah.

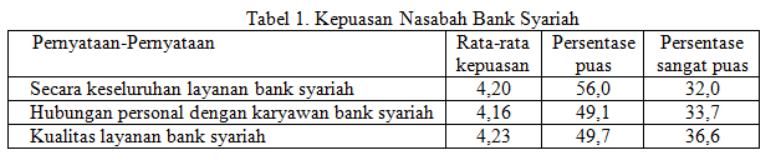

Dari tabel 1 dapat dilihat bahwa persentase nasabah yang puas terhadap bank syariah sebesar $56 \%$ dan merasa sangat puas sebesar 32\%,sedangkan sisanya merasa biasa-biasa saja. Hal ini menunjukkan bahwa bank syariah dengan baik telah memberikan layanan yang memuaskan kepada nasabah. Sedangkan untuk hubungan personal dengan karyawan, 49,1\% menyatakan puas dan $33,7 \%$ merasa sangat puas dan sisanya menyatakan biasa-biasa saja. Untuk kualitas layanan bank syariah, 49,7\% menjawab puas dan $36,6 \%$ menyatakan sangat puas dan sisanya menyatakan biasa-biasa saja. Oleh karena itu, bank syariah seharusnya membangun budaya kualitas melalui pengadaptasian sebuah sistem kualitas dalam sisi operasional dan manajerialnya

Pengujian analisis jalur dengan menggunakan bantuan program Lisrel 8.3 for Windows, setelah lebih dahulu dilakukan analisis faktor untuk mengetahu jumlah faktor yang terbentuk. Dalam penentuan pengaruh variabel penelitian secara keseluruhan didapat nilai koefisien jalur dari penjumlahan seluruh variabel eksogenus terhadap variabel endogenus. Nilai koefisien jalur (berdasarkan estimate) variabel faktor kualitas jasa dapat dilihat pada gambar 4.1 berikut ini:

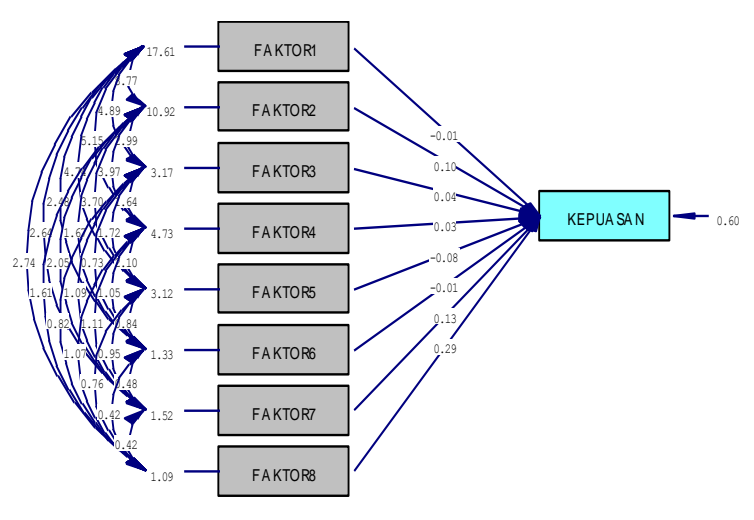

Gambar 2 Koefisien Jalur dari Faktor

Kualitas Jasa Perbankan Syariah terhadap Kepuasan Pelanggan 
Dari hasil analisis jalur, diperoleh nilai Chi-Square $=0,00$. Menurut Ghazali dan Fuad (2005) Chi-square menunjukkan penyimpangan yang terjadi antara matrik kovarian dengan matrik korelasi. Nilai ChiSquare dibawah 0,05 menunjukkan suatu model sudah fit atau sesuai dengan data dan nilai Chi-Square $=0$, menunjukkan model fit sempurna (fit of perfect). Sedangkan Root Mean Square Error of Approximation (RMSEA) menunjukkan penyimpangan model dengan data.

Menurut Ghazali dan Fuad (2005) yang mengutip dari Brownedan dan Crudeck (1993) menjelaskan nilai RMSEA yang dapat diterima harus dibawah 0,05 dengan nilai probabilitas diatas 0,05. Dari gambar 4.1 didapat nilai $\mathrm{RMSEA}=0,000$ dan $\mathrm{p}$-value $=$ 1,000 .

Untuk mengetahui besar proporsi pengaruh variabel faktor kualitas jasa perbankan syariah dihitung dengan menggunakan persamaan koefisien distribusi (KD), yaitu (Sitinjak dan Sugiarto, 2006):

$\mathrm{KD}=\mathrm{r}^{2} \times 100 \%$

$\mathrm{KD}=$ Koefisien Determinasi

$r=$ Nilai Koefisien Jalur

Variabel-variabel faktor kualitas jasa perbankan syariah yang berpengaruh secara signifikan terhadap kepuasan pelanggan yaitu; reliability (F1) sebesar $0,01 \%$, tangible (F2) sebesar $1 \%$, assurance (F3) sebesar 0,16\%, responsiveness $(\mathrm{F} 4)$ sebesar $0,09 \%$, emphaty (F5) sebesar 0,64\%, competence (F6) sebesar $0,01 \%$, Knowing the customer (F7) sebesar $1,69 \%$, dan compliance (F8) sebesar 8,41\%. Dalam analisis jalur diperoleh kedelapan faktor mempengaruhi secara langsung sebesar $12,01 \%$ dan mempengaruhi secara tidak langsung sebesar 36\% terhadap kualitas jasa diperbankan syariah dan sisanya sebesar $51,99 \%$ dipengaruhi oleh variabel lain.

\section{PEMBAHASAN}

Dari hasil analisis dan pembahasan diperoleh beberapa kesimpulan berikut (1)Analisis jalur memperlihatkan bahwa faktor-fakor kualitas jasa pada perbankan syariah mempengaruhi secara langsung sebesar $12,01 \%$ dan mempengaruhi secara tidak langsung sebesar $36 \%$ terhadap kepuasan pelanggan dan sisanya sebesar $51,99 \%$ dipengaruhi oleh variabel lainnya. (2)Persentase tingkat kepuasan nasabah terhadap keseluruhan layanan bank syariah yang merasa puas sebesar $56 \%$ dan yang sangat puas sebesar $32 \%$, sedangkan untuk hubungan personal dengan karyawan bank syariah, persentase nasabah yang merasa puas sebesar $49,1 \%$ dan $33,7 \%$ nasabah yang merasa sangat puas. Untuk kualitas layanan bank syariah, 49,7\% nasabah merasa puas dan $36,6 \%$ merasa sangat puas. (3) Hasil analisis jalur dapat dipergunakan untuk melengkapi strategi perbaikan kualitas dengan memperhatikan prioritas fakor-faktor yang mempengaruhi kualitas layanan. Analisis ini memperlihatkan prioritas perbaikan kualitas dimulai dari faktor reliability (F1), dan competence (F6), kemudian responsiveness $(\mathrm{F} 4)$, assurance (F3), emphaty (F5), tangible (F2), knowing the customer (F7) dan compliance (F8). Dengan demikian diharapkan kualitas jasa perbankan syariah dapat meningkat.

Hasil penelitian ini sejalan dengan penelitian sebelumnya Othman dan Lynn Owen dari University of Wales pada tahun 2001 mengembangkan model pengukuran kualitas jasa.

\section{SIMPULAN}

Dari hasil analisis dan pembahasan diperoleh beberapa kesimpulan berikut (1)Analisis jalur memperlihatkan bahwa faktor-fakor kualitas jasa pada perbankan syariah mempengaruhi secara langsung sebesar $12,01 \%$ dan mempengaruhi secara tidak langsung sebesar $36 \%$ terhadap kepuasan pelanggan dan sisanya sebesar $51,99 \%$ dipengaruhi oleh variabel lainnya.

\section{DAFTAR RUJUKAN}

Assael, Henry., 1998, Consumer Behavior and Marketing Action, $6^{\text {th }}$ ed., SouthWestern Collage Publishing, Cincinnati, Ohio. 
Bank Indonesia, 2000, Penelitian Potensi, Preferensi dan Perilaku Masyarakat terhadap Bank Syariah di Wilayah Jawa Tengah dan Daerah Istimewa Yogyakarta, Internet, Dari Situs Bank Indonesia.

Frutcher, B., 1954, Introduction to Factor Analysis, D. Van Nostrand Company, Inc., Toronto, New York.

Ghazali Imam, Fuad., 2005, Structural Equation Model, Teori dan Aplikasi dengan Lisrel 8.54, Bagian Penerbit Undip, Semarang

Gronross, C., 1990, A Service Quality Model and Its Marketing Implementation, European Journal of Marketing, Vol. 18 No. 4.

Karim, R. T., 2005, Prospek dan Tantangan Perbankan Syariah 2006, Economic Review Journal No. 202

Lovelock, Christoper H., 1992, Managing Service: Marketing, Operating and Human Resources, Prentice Hall International, Inc., New Jersey. USA.

Mueller, Ralph O., 1996, Basic Principles of Structural Equation Modeling: An Introduction to LISREL and EQS, Springer Verlaag, Inc., New York

Nasution, M.N., 2004, Manajemen Jasa Terpadu, Penerbit Ghalia Indonesia, Bogor

Norusis, M., 1985, SPSS Introductory Guide: Basic Statistic and Operations, McGraw-Hill, London

Othman, A., Owen, L., 2001, Adopting and Measuring Customer Service Quality (SQ) in Islamic Banks: A Case Study in Kuwait Finance House. International Journal of Islamic Financial Services Vol. 3. No. 1.
Othman, A., Owen, L., 2001, The Multi Dimensionality of Carter Model to Measure Customer Service Quality (SQ) in Islamic Banking Industry: A Study in Kuwait Finance House. International Journal of Islamic Financial Services Vol. 3. No. 4.

Parasuraman, A., Zeithaml, Valarie A., and Berry, L.L., 1985, A Conceptual Model of Service Quality and Its Implication for Future Research, Journal of Marketing, Vol. 49

Purnama, Nursya'bani, 2006, Manajemen Kualitas Perspektif Global, Penerbit Ekonisia, Fakultas Eknomi UII, Yogyakarta

Rust, R.T. and Oliver, R., 1994, Service Quality, SEGE Publication: London

Singaribun, M., Effendi, S., 1989, Metode Penelitian Survey, LP3ES. Jakarta.

Sitinjak, Tumpal JR., Sugiarto, 2006, Lisrel, Penerbit Graha Ilmu, Yogyakarta

Sugiyono, 2002, Metode Penelitian Administratif, Penerbit Alfabeta, Bandung

Trihendradi,C, 2004, Statistik Inferen, Penerbit Andi Offset, Yogyakarta

Tjiptono, F., 1997, Prinsip-Prinsip Total Quality Service, Penerbit Andi Offset, Yogyakarta. 